\title{
Studies on Ecological Changes and Control of Weeds in Upland Irrigation Culture
}

II. Effect of Soil Moisture on Emergence and Growth of Principal Annual Weeds on Upland Fields

\section{Hiroyuki Yамамото and Torao Онва}

Kyushu Agricultural Experiment Station, Miyakonojo, Miyazaki

\section{Summary}

A research reported herein was carried out to determine the effect of soil moisture on emergence and growth of principal twelve species of annual weeds on upland fields. Results obtained are summarized as follows.

1. Optimum soil moisture for emergence of each species was little different, and it ranged from 70 to 85 percent of the maximum water holding capacity.

2. Optimum soil misture for growth of Cyperus iria and winter annual weeds was near upon the maximum water holding capacity. As to the other summer annual weeds, it ranged from 70 to 85 percent of the maximum water holding capacity.

3. Emergence and growth of weeds was suppressed by higher or lower soil moisture than the optimum soil moisture, the tendency influenced was different on weed species. Therefore, those weed species were grouped into four classes.

\section{暖地型牧草と雑草の出芽・生育に与える環境条件の影響について*}

\author{
農林省農事試験場＼cjkstart野口勝可・中山兼 徳
}

わが国の暖地においては，寒地型牧草は夏季の高温期 に夏枯れをおこす。そのため，寒地型牧草は冬作物とし て作付けし，これと組合せて夏に暖地型牧草を導入，利 用する研究 ${ }^{2)}$ が進められているが，農家への普及速度は 遅い。その原因の一つとして, 暖地型牧草の出芽・初期 生育の不安定と, それに伴ら雑草害があげられ, その解 決が強く求められている ${ }^{4,5)}$ 。本研究は以上のような現 状を考慮して設定したものであり，代表的な暖地型牧草 について, 出芽・初期生育と温度・土堷水分との関係, さらに刈取り後の再生力などを, 競合種の雑草との対比 に拉いて検討した。若干の知見を得たので坏告する。

\section{1. 主要畑雑草の発生時期}

\section{(1) 材料 と方法}

1974 年 2 月 27 日に，前年秋に雑草種子を混入してお
いた土壤を 1/5,000 a ワグネルポットにつめ， 戸外に設 置, 適宜かん水して, 雑草の自然環境下における発生の 時期, 消長を調查した。また, 土壤温度勾配装置（深さ $2.5 \mathrm{~cm}$ に充塡した槽内土壤を $5 \sim 40^{\circ} \mathrm{C}$ の間で直線的に, あるいは任意の温度勾配で維持できるもので, 大起理化 製）を用いて雑草の出芽と温度との関係を調べた。供試 草種は関東地方の主要畑雑草であるシロザ，オオイヌタ デ，イヌビユ,メヒシバ，スベリヒユ，カヤツリグサで ある。

\section{（2）試 験 結 果}

各程草の発生消長を最終出芽本数を 100 とした時の累 積出芽率であらわし，第 1 図に示した。最終出芽本数は シロザ,オオイヌタデ，イヌビユ,メヒシバ, スベリヒ ユ，カヤツリグサそれぞれポット当たり $79,162,62$, $144 ， 54 ， 124$ 本であった。第 1 図によると, 供試雑草の

\footnotetext{
* 本研究の要旨は日本雑草防除研究会第 14 回講演会 (1975) において発表した。
} 


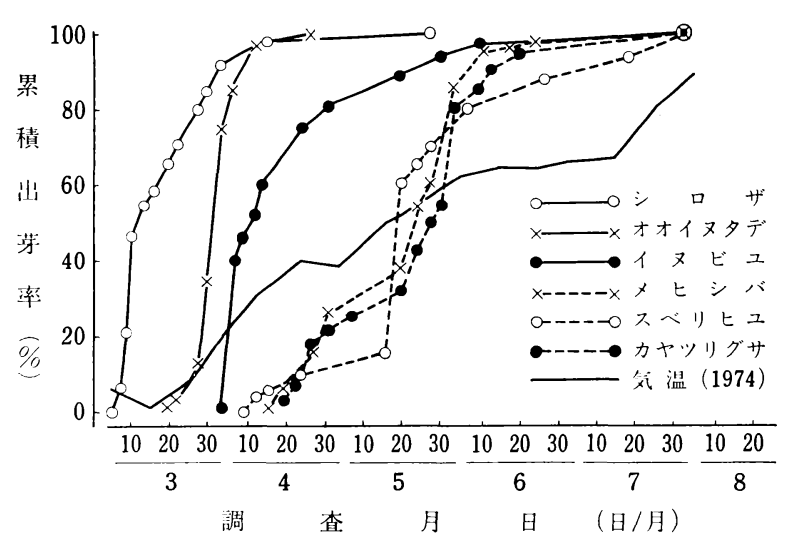

第 1 図主要畑雑草の自然発生の経過

うちシロザの出芽が最も早く(出芽始期 3 月上旬), 次 いでオオイヌタデ，イヌビュ（同 4 月上旬）の順であっ た。メヒシバ, スベリヒュ,カヤツリグサはこれよりも 遅く，出芽始期は 4 月中旬であった。また，出芽始期の 早い草種は発生期間が短い傾向にあり，出芽始期から累 䄼出芽率 $80 \%$ に達するまでの期間で比べると，シ口 ザ，オオイヌタデは 20 日以内，イヌビユが約 30 日，メ ヒシバ，スベリヒユ，カヤツリグサでは 50〜 60日であ った。

温度公配装置を用いた試験の結果によれば，出芽最低 温度・出芽適温は次のようであった。シロザ: 6 〜 7 ${ }^{\circ} \mathrm{C} \cdot 10^{\circ} \mathrm{C}$ 以上, メヒシバ : $13 \sim 15^{\circ} \mathrm{C} \cdot 20^{\circ} \mathrm{C}$ 以上, スベ リヒュ : $12 \sim 13^{\circ} \mathrm{C} \cdot 20^{\circ} \mathrm{C}$ 以上, カヤッリグサ : $14 \sim 16$ ${ }^{\circ} \mathrm{C} \cdot 20^{\circ} \mathrm{C}$ 以上。

\section{以上の両試験の結果か}

ら, 各雑草の出芽期と日 平均気温との関係をまと めると第 1 表のようにな る。なお，オオイヌタデ とイヌビュは自然条件に おける発生消長のデータ から推定した。これらと 平年の日平均気温をもと
第 1 表 主要畑雑草の出芽 と気温との関係

\begin{tabular}{|c|c|c|}
\hline \multirow{2}{*}{ 草種 } & \multicolumn{2}{|c|}{ 日平均気温 } \\
\hline & 出芽始期 & 出芽盛期 \\
\hline シ ロ ザ & $6 \sim 7$ & $10 \sim 13{ }^{\circ} \mathrm{C}$ \\
\hline オオイヌタデ & $7 \sim 10$ & $10 \sim 15$ \\
\hline $1 \times 匕^{*}=$ & $10 \sim 13$ & $20^{\circ} \mathrm{C}$ 前後 \\
\hline メ ヒ シ ハ & $13 \sim 15$ & $20^{\circ} \mathrm{C}$ 以上 \\
\hline スペりヒ二 & $12 \sim 13$ & $20^{\circ} \mathrm{C} \quad$ I \\
\hline カナツリグサ & $14 \sim 16$ & $20^{\circ} \mathrm{C}$ \\
\hline
\end{tabular}

に, 関東地方平担部における雑草の発生について, 暖地 型牧草の播種期と対応してきとめると，4 月上・中旬の 早播きではシロザ，オオイヌタデ，4月下旬から 5 月上 ・中旬の播種ではオオイヌタデ，イヌビユが，5月下䏱 以降の播種ではメヒシバ，スベリヒュ，カヤッリグサな どがそれぞれ主たる牧草の競合種になると考えられる。 耕地雑草の発生についではすでに荒井ら ${ }^{1)} の$ 報告があ り, 以上の結果と大略類似しているが, 雑草の出芽期の
気温は本試験で得られた結果の方が低 い。また, 雑草の発生消長を作物の播種 期との関連で整理したものに竹村ら ${ }^{6)} の$ 報告があり，本試験の結果とほぼ一致し ている。

\section{2. 暖地型牧草, 雑草の出芽・ 初期生育と温度との関係}

\section{（1）材料と方法}

代表的な暖地型牧草であるローズグラ ス (品種カタンボラ), シコクビエ（祖 谷在来 $)^{2,3)}$, および雑草としては比較的 早い時期に出芽するオオイヌタデ, 遅い メヒシバを供試し，そよぞれ $1 / 5,000 \mathrm{a}$ ワグネルポットに 100 粒宛散播した。なお，オオイヌタ デについては試験 1 で用いた同じ土壌をポットにつめ た。施肥量は 3 要素成分でそれぞれ $0.5 \mathrm{~g}$ 宛施用した。 それらのポットを自然光の人工気象箱に設置し, (1) 日 平均気温 $15^{\circ} \mathrm{C}$ (昼間 $17.5^{\circ} \mathrm{C}$ ・夜間 $12.5^{\circ} \mathrm{C}$ ), (2) 同 $20^{\circ} \mathrm{C}$ $\left(22.5^{\circ} \mathrm{C} \cdot 17.5^{\circ} \mathrm{C}\right)$, (3) 同 $25^{\circ} \mathrm{C}\left(27.5^{\circ} \mathrm{C} \cdot 22.5^{\circ} \mathrm{C}\right)$ の温度 条件を設定し, 出芽・初期生育の様相を検討した。 3 反 復で, 試験期間は 1974 年 4 月 2 日から 30 日までとし た。

\section{（2）試 験 結 果}

最終の出芽本数は各草種とも温度条件による差はみら れなかったが, 出芽の経過は, 第 2 図に示すよ5に, 草 種によりかなり異なった。すなわち，メヒシバは 4 種の なかで最も出芽が遅れ，とくに低温条件ほどその傾向が 著しく, $15^{\circ} \mathrm{C}$ の条件では $50 \%$ の累積出芽率に達するの に約 2 週間を必要とした。これに対して, シコクビェ, オオイヌタデは出芽が早く, 低温条件でもすみやかであ り, $15^{\circ} \mathrm{C}$ の条件で 1 週間以内に $50 \%$ の累積出芽率を越 えた。ローズグラスの出芽始期および出芽の経過は 15 ${ }^{\circ} \mathrm{C}, 20^{\circ} \mathrm{C}$ ではメヒシバとシコクビエ並びにオオイヌタデ の中間であり, また， $25^{\circ} \mathrm{C}$ の条件ではシコクビエ並びに オオイヌタデと扂がなかった。

播種 29 日後に草丈・主茎長, 生体重について調査し た結果は第 2 表に示すと打りであり, 各草種とも高温条 件ほど旺盛な生育を示した。草丈・主茎長では各温度条 件ともシコクビエの生育が最もまさっな。ローズグラス とメヒシバは同様な生育を示したが， $25^{\circ} \mathrm{C}$ 条件にお打 る前者の生体重はシコクビエとほぼ同等で, メヒシバに まさる傾向を示した。オオイヌタデは主茎長では他の草 種に劣ったが，生体重は大きく，とくに $15^{\circ} \mathrm{C}$ 条件にお ける生体重はシコクビエの 2.6 倍, ローズグラスの 12.5 

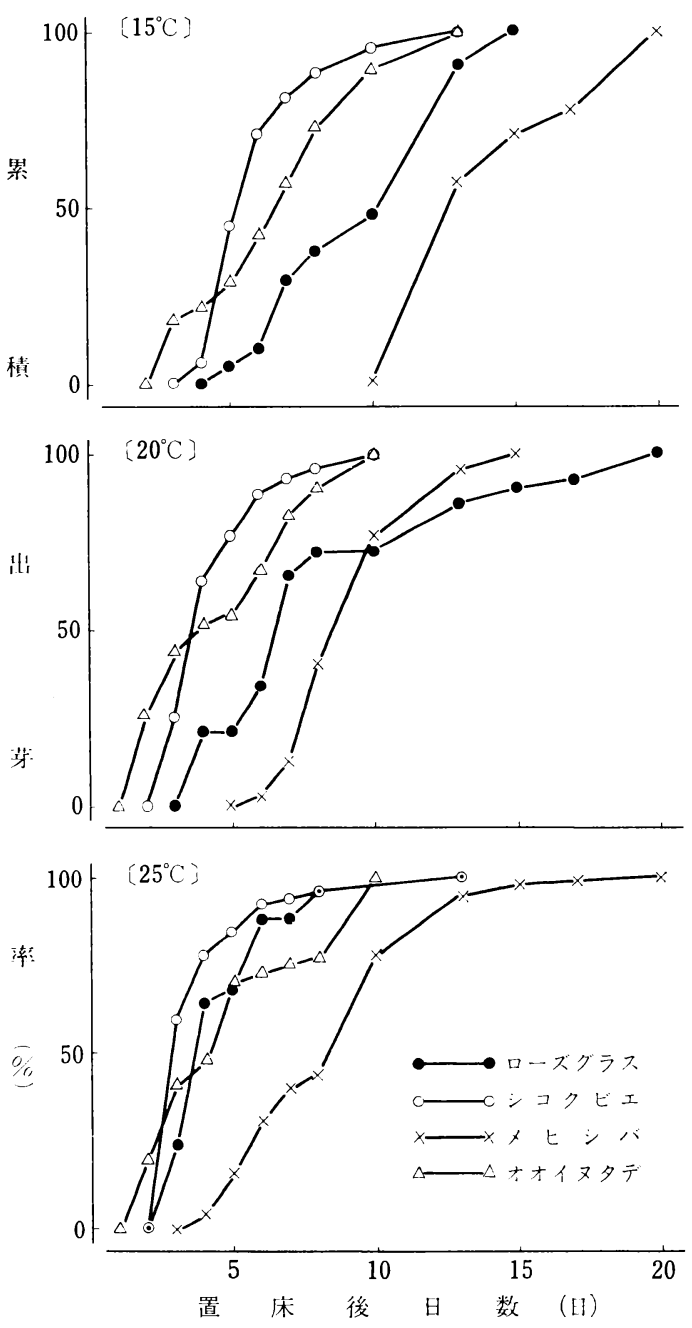

第 2 図 温度条件の違いが暖地型牧草と雑草の出芽 に及ぼす影響

注）〔〕内の温度は日平均気温

第 2 表 温度条件の違いが牧草と雑草の初期生育に 及ぼす影響

\begin{tabular}{|c|c|c|c|c|c|c|c|c|}
\hline \multirow{2}{*}{ 草 } & \multicolumn{4}{|c|}{ 丈・主 茎 長 } & \multicolumn{4}{|c|}{ 地上部生体重 } \\
\hline & $15^{\circ} \mathrm{C}$ & $20^{\circ} \mathrm{C}$ & $25^{\circ} \mathrm{C}$ & $\begin{array}{l}\text { LSD } \\
5 \%\end{array}$ & $15^{\circ} \mathrm{C}$ & $20^{\circ} \mathrm{C}$ & $25^{\circ} \mathrm{C}$ & $\begin{array}{l}\text { LSD } \\
5 \%\end{array}$ \\
\hline ローズグラス & $\begin{array}{c}\mathrm{cm} \\
3.8\end{array}$ & $\begin{array}{c}\mathrm{cm} \\
14.3\end{array}$ & $\begin{array}{c}\mathrm{cm} \\
32.8\end{array}$ & $\begin{array}{l}\mathrm{cm} \\
11.3\end{array}$ & 0.06 & $0.34^{\mathrm{g}}$ & $2.31^{\mathrm{g}}$ & $0.60^{\mathrm{g}}$ \\
\hline シコクビエ & 8.0 & 31.3 & 42.7 & 8.0 & 0.26 & 1.47 & 2. 16 & 0.58 \\
\hline × & 3.6 & 18.7 & 38.4 & 4.1 & 0.04 & 0.61 & 1.58 & 0.68 \\
\hline オオイヌタデ & 4.1 & 11.5 & 14.1 & 5.6 & 0.70 & 1.99 & 2.57 & 0.98 \\
\hline L S D $5 \%$ & 1.7 & 7.0 & 5.8 & & 0.13 & 0.59 & n.s. & \\
\hline
\end{tabular}

注）生体重は倜体当たり。播種 29 日目の調查

倍に達した。

以上の結果から, シコクビエは低温発芽性がよく, 初
期生育が旺盛で雑草との競争力が強いことが推察でき た。これは茨木 ${ }^{2)}$ の報告と一致している。一方，ローズ グラスはメヒシバより低温発芽性はややまさるものの, 初期生育では差がなく, 低温条件においては雑草との競 争力は大きくない。したがって，低温条件における播種 では，オオイヌタデなどの雑草害を大きくうけやすいと 考えられる。

\section{3. 暖地型牧草, 雑草の出芽・初期生育 と土壤水分との関係}

\section{（1）材料 と方法}

1973 年 5 月 15 日および 6 月 13 日の 2 回にわたり, 口 ーズグラス（カタンボラ）とメヒシバを供試し，火山灰 土壤を充塓した $50 \mathrm{~cm} \times 50 \mathrm{~cm}$ のポットに播種した。播 種量はローズグラス $0.75 \mathrm{~g}$ (約 3,500 粒)，メヒシバは 5 月播種で 200 粒, 6 月播種では 400 粒とし, 散播し た。施肥量はポット当たり 3 要素を成分で各々 $3 \mathrm{~g}$ とし た。これらのポットを大起理化製雨滴発生装置を用い, (1) 湿潤区 ( $6 \mathrm{~mm} /$ 日かん水), (2) 中湿区 ( $4 \mathrm{~mm} /$ 日), (3) 乾燥区 $(2 \mathrm{~mm} /$ 日) の土壤水分条件に設定した。土 埣水分は深さ $2 \mathrm{~cm}$ に設置した石静ブロックで測定し, 測定值は $6,4,2 \mathrm{~mm} /$ 日かん水区がそれぞれ 5 月播種 区で $0.5 \sim 0.7$ (含水比 $50 \%$ 以上), $4.7 \sim 7.6$ (34 36 $\%), 12.2 \sim 15.8 \mathrm{k} \Omega(28 \sim 32 \%), 6$ 月播種区で $0.3 \sim$ 0.5 (50\%以上), $1.2 \sim 2.0(41 \sim 45 \%), 8.9 \sim 12.2 \mathrm{k} \Omega$ (31 32\%) であった。なお，ポットは降雨探知機付移 動ハウスの中に設置し, 自然の降雨を遮断した。5月播 種区は 6 月 6 日， 6 月播種区は 6 月 21 日に出芽本数と 生体重を調査した。試験は 2 反復で実施した。

\section{(2) 試 験 結 果}

ローズグラス拉よびメヒシバの出芽・生育に与える土 壤水分の影響は第 3 表に示すように著しく，両試験期と も出芽・生育は 湿潤区 $>$ 中湿区 $>$ 乾燥区 であった。 5

第 3 表 ローズグラスとメヒシバの出芽・生育と土 壤水分との関係

\begin{tabular}{l|} 
試驗 \\
時期
\end{tabular}

注）本数はポット当たり, 生休重は個体当たり 
月播種区に比べ 6 月播種区が乾湿による出芽・生育の差 は小さいれ，石高ブロックの抵抗值にみられるように， 6 月が梅雨期に当たり，蒸発量が少なく，同一かん水量 でも土壤水分が多かったためと考えられた。両草種の間 では乾湿による出芽・生育の差はローズグラスの方が小 さい傾向を示した。

以上の結果から, 湿潤区における深さ $2 \mathrm{~cm}$ の石膏ブ ロック抵抗值が $1 \mathrm{k} \Omega$ 以下（含水比 $50 \%$ 以上）であっ たことからみて, 両草種とも出芽に適する土壤水分はき わめて高く，また抵抗值が $10 \mathrm{k} \Omega$ 以上（含水比 $32 \%$ 以下）の場合には出芽が著しく抑制されることが推定で きた。ローズグラスの出芽にとって，播種後 10 日間に $20 \mathrm{~mm}$ 以上の降雨が必要とする報告がある ${ }^{4}$ が, 本試験 の結果からも，ローズグラスの出芽には土培水分の影響 が大きいことがわかった。

\section{4. 暖地型牧草の刚取り前の遮光が 再生に及ほす影響}

\section{（1）材料と方法}

ローズグラス (カタンボラ) とシコクビエ（祖谷在来） を供試，1973 年 5 月 29 日に，3 要素抒よび石灰を各々

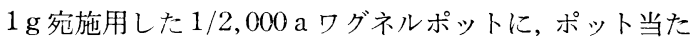
り 100 粒播種した。試験区は，(1) 播種 30 日後より 84 $\%$ 遮光区, (2) 同 $75 \%$ 遮光区, (3) 無遮光対照区 を設 けた。遮光は黒色寒冷紗を用い, 播種 30 日後から 16 日 間実施し，その生育一の影響を調查するとともに，刈取 り（第 1 回，刘取り高さ $10 \mathrm{~cm}$ ）後直ちにポット当たり 硫安 $5 \mathrm{~g}$ を追肥し，露光条件におう，第 1 回刚取り後 22 日目に打ける再生量（第 2 回刚取り）を調查した。試験 は 3 反復で行なった。

\section{（2）試 験 結 果}

第 4 表に示すように，ローズ グラスでは第 1 回刚取り時にお いて遮光処理による草丈の差は みられなかったが, 生体重は減 少した。刚取り後の再生量草 丈, 生体重とも遮光区で対照区 に有意に劣った。シコクビエで は第 1 回刈取り時においても澏 光の影響が草丈, 生体重ともに みられ，とくに $84 \%$ 遮光区で は有意に対照区に劣り，刈取り 後の再生は著しく不良で荡っ た。

以上のように，第 1 回刈取り
第 4 表 暖地型牧草の刈取り前の遮光が再生に及ぼ 寸影響

\begin{tabular}{|c|c|c|c|c|c|c|c|c|c|c|}
\hline \multirow{3}{*}{ 試 } & \multirow{3}{*}{ 験 } & \multirow{3}{*}{ 区 } & \multicolumn{4}{|c|}{ ローズクラス } & \multicolumn{4}{|c|}{ シコクビエ } \\
\hline & & & \multicolumn{2}{|c|}{$\begin{array}{l}\text { 第 } 1 \text { 回难形 } \\
\text { b時 }\end{array}$} & \multicolumn{2}{|c|}{$\begin{array}{l}\text { 䨔 } 2 \text { 國杊取 } \\
\text { 時 }\end{array}$} & \multicolumn{2}{|c|}{$\begin{array}{l}\text { 第 } 1 \text { 回灲攻 } \\
\text { b)侍 }\end{array}$} & \multicolumn{2}{|c|}{$\begin{array}{l}\text { 第 } 2 \text { 回刈取 } \\
\text { 门時 }\end{array}$} \\
\hline & & & 草丈 & 生休䨘 & 草大 & 生休重 & 草丈 & 生休重 & 草丈 & 生体重 \\
\hline $84 \%$ & 尷 & 光区 & $\begin{array}{l}\mathrm{cm} \\
51\end{array}$ & $28.2^{\mathbf{g}}$ & $\begin{array}{l}\mathrm{cm} \\
40\end{array}$ & 87.7 & 50 & 115.4 & 21 & 3. \\
\hline $75 \%$ & & ” & 50 & 31.3 & 43 & 101.0 & 57 & 167.3 & 34 & 33.2 \\
\hline 対 & 照 & 区 & 52 & 46.8 & 59 & 181.7 & 61 & 227.4 & 55 & 194.0 \\
\hline L S & $\mathrm{D}$ & $5 \%$ & n.s. & n.s. & 10 & 79.1 & 6 & 66.3 & 6 & 28.4 \\
\hline
\end{tabular}

注）生体重法织ット当たり

前の遮光は再生に大きな影響を及ぼすことが明らかにで きた。とくに，シコクビェは遮光に弱い特性をもつこと が認められた。

\section{5. 刈取り処理が雑草の再生に及ぼす影響}

\section{(1) 材料と方法}

シロザ, オオイヌタデ, イヌビユ, メヒシバ, スベリ ヒユ，カヤッリグサを供試し，1974 年 5 月 20 日にペー パーポットに播種， 6 月 15 17 日に戋場に畦幅 $30 \mathrm{~cm}$, 株間 $15 \mathrm{~cm} ， 1$ 本立てで定植した。 7 月 30 日に地ぎわ から $5 \mathrm{~cm}$ および $10 \mathrm{~cm}$ の高さで切除し, 残株からの再 生状態を 30 日後に調査した。肥料は 3 要素成分で $1 \mathrm{~kg}$ /a 施用した。各雑草とも 16 個体を供試した。

\section{(2) 試 験 結 果}

们取り処理が雑草の再生に及ぼす影響は, 第 5 表に示 すように，草種間で大きく異なった。オオイヌタデは全 く再生せず，す心゙て枯死した。シロザも再生力が弱く， 刈取り高さ $5 \mathrm{~cm}$ では $75 \%$ が， $10 \mathrm{~cm}$ では $31 \%$ が枯死 した。しかし，メヒシバ，スベリヒユ，カヤツリグサ， イヌビユは全個体が再生した。

第 5 表 刚取りが雑草の再生に与える影響

\begin{tabular}{|c|c|c|c|c|c|c|c|c|c|c|}
\hline \multirow[b]{2}{*}{ 草 } & \multirow{2}{*}{$\begin{array}{l}\text { 杊取り } \\
\text { の } \\
\text { 高 }\end{array}$} & \multicolumn{2}{|c|}{ 刈 取 り 時 } & \multicolumn{2}{|c|}{ 刈取り正微 } & \multirow{2}{*}{ 再生枨淘 } & \multicolumn{3}{|c|}{ 杊取り 30 日後 } & \multirow{2}{*}{$\frac{\mathrm{B}}{\mathrm{A}}$} \\
\hline & & $\begin{array}{l}\text { 草丈. } \\
\text { 主茎髟 }\end{array}$ & 䒱 - 分 & 侧芽数 & $\begin{array}{c}\text { 乾物重* } \\
\text { (A) }\end{array}$ & & $\begin{array}{l}\text { 草丈· } \\
\text { 主蒸层 }\end{array}$ & $\begin{array}{l}\text { 莠・分 } \\
\text { 数 }\end{array}$ & $\begin{array}{c}\text { 乾物重 } \\
(\mathrm{B})\end{array}$ & \\
\hline シ & $\begin{array}{l}5^{\mathrm{cm}} \\
10\end{array}$ & $\begin{array}{l}\mathrm{cm} \\
102\end{array}$ & $84^{\text {A }}$ & $\begin{array}{l}0.9^{\text {個 }} \\
3.8\end{array}$ & $\begin{array}{l}1.46^{\mathrm{g}} \\
3.24\end{array}$ & $\begin{array}{l}25^{\%} \\
69\end{array}$ & $\begin{array}{l}\quad \mathrm{cm} \\
17.3 \\
33.0\end{array}$ & $\begin{array}{r}\text { 木 } \\
6.5 \\
37.6\end{array}$ & $\begin{array}{r}\mathbf{g} \\
1.84^{2} \\
7.93\end{array}$ & $\begin{array}{l}1.3 \\
2.5\end{array}$ \\
\hline オオイヌタデ & $\begin{array}{r}5 \\
10\end{array}$ & 63 & 13 & $\begin{array}{l}0.7 \\
2.6\end{array}$ & $\begin{array}{l}0.40 \\
0.61\end{array}$ & $\begin{array}{l}0 \\
0\end{array}$ & $\begin{array}{l}0 \\
0\end{array}$ & $\begin{array}{l}0 \\
0\end{array}$ & $\begin{array}{l}0 \\
0\end{array}$ & $\begin{array}{l}0 \\
0\end{array}$ \\
\hline イ 又 & $\begin{array}{r}5 \\
10\end{array}$ & 42 & 70 & $\begin{array}{l}23.1 \\
34.8\end{array}$ & $\begin{array}{l}0.97 \\
0.69\end{array}$ & $\begin{array}{l}100 \\
100\end{array}$ & $\begin{array}{l}42.1 \\
52.4\end{array}$ & $\begin{array}{r}71.0 \\
105.4\end{array}$ & $\begin{array}{l}13.01 \\
19.88\end{array}$ & $\begin{array}{l}13.4 \\
28.8\end{array}$ \\
\hline ×ヒシ バ & $\begin{array}{r}5 \\
10\end{array}$ & 98 & 110 & $\begin{array}{l}22.5 \\
44.0\end{array}$ & $\begin{array}{l}1.94 \\
4.90\end{array}$ & $\begin{array}{l}100 \\
100\end{array}$ & $\begin{array}{l}58.9 \\
70.0\end{array}$ & $\begin{array}{l}26.2 \\
49.0\end{array}$ & $\begin{array}{l}12.45 \\
25.81\end{array}$ & $\begin{array}{l}6.4 \\
5.3\end{array}$ \\
\hline スペリヒ二 & $\begin{array}{r}5 \\
10\end{array}$ & 21 & 175 & $\begin{array}{r}6.3 \\
50.1\end{array}$ & $\begin{array}{l}0.75 \\
1.04\end{array}$ & $\begin{array}{l}100 \\
100\end{array}$ & $\begin{array}{l}27.3 \\
37.2\end{array}$ & $\begin{array}{l}285.6 \\
692.7\end{array}$ & $\begin{array}{r}7.95 \\
22.33\end{array}$ & $\begin{array}{l}10.6 \\
21.5\end{array}$ \\
\hline カナツリグサ & $\begin{array}{r}5 \\
10\end{array}$ & 50 & 9 & $\begin{array}{r}11.1 \\
9.8\end{array}$ & $\begin{array}{l}1.65 \\
2.70\end{array}$ & $\begin{array}{l}100 \\
100\end{array}$ & $\begin{array}{l}38.9 \\
52.3\end{array}$ & $\begin{array}{r}9.0 \\
14.0\end{array}$ & $\begin{array}{r}7.50 \\
11.32\end{array}$ & $\begin{array}{l}4.6 \\
4.2\end{array}$ \\
\hline
\end{tabular}

注）調笨は估体当たり

*拔取った別の株の値から計算で求学心。

**再生株莩=(耹生株数/刘取り株数) $\times 100$ 
再生量を刈取り後再生育した雑草の地上部乾物重と草 丈・主茎長からみると, 刈取り高さで若干草種間に変動 はみられるが，メヒシバとイヌビユが最も大きかった。 スベリヒユは刈取り高さ $10 \mathrm{~cm}$ ではメヒシバなどに遜色 ない生育量を示したが， $5 \mathrm{~cm}$ の刈取り高さでは著しく 劣った。カヤツリグサ, シロザの再生量は小さかった。 また, 再生の度合を刈取り直後の残存重量に対寸る刈取 り 30 日後の重量の割合でみると，イヌビユが最も大き く, 次いでスベリヒユ,メヒシバ, カヤッリグサ, シロ ザの順であった。

前述したように，刏取り高さも再生に強く影響し，10 $\mathrm{cm}$ より $5 \mathrm{~cm}$ の方が再生力が弱く, とくにシロザ，ス ベリヒユはその傾向が著しかった。

なお，刈取り直後の残存株の側芽数の多い草種は再生 力が強い傾向が認められた。

以上の結果は, 競合のない条件のものであり, 競合条 件ではメヒシバ，スベリヒユ，イヌビユなどは立性にな り，また刈取り直後の残存株の側芽数，眝蔵養分なども 異なるので，以上の結果を実際の圈場条件に適応させる には，さらに検討が必要であるが，们取り後の再生につ いて一応の傾向を明らかにすることができた。

\section{6. 考察}

実際の栽培条件では, 気温, 土壤水分, 雑草との競 合, 刈取り技術などが相互に関連して, 暖地型牧草の出 芽・生育に影響を与える。したがって, 本試験の結果の みで暖地型牧草の戋場への導入のための結諭を得ること はできない。しかし，それに対するいくつかの知見は得 ることができたと考えられるので，とくに雑草防除の面 から暖地型牧草の出芽・生育の安定について若干の考察 をしておくことにする。

（1） シコクビエは低温発芽性で, $15^{\circ} \mathrm{C} の$ 条件でも オオイヌタデとほぼ同様に出芽し, しかも短期間に出芽 を終える。また草丈の伸長も多くの競合雑草にまさるの で, 雑草との競合に強い特性をもっているといえる。と くに，シロザ，オオイヌタデなど夏生 (早，中）雑草1) の発生期 (日平均気温 $10 \sim 15^{\circ} \mathrm{C}$ ) とメヒシバ, スベリヒ 二などの夏生（晚）雑草の発生期（日平均気温 $20^{\circ} \mathrm{C}$ 以 上）の中間に播種した場合には，雑草害をうけるおそれ が少ないことが推定できる。

しかし, 遮光を受けた場合の再生力がきわめて弱い性 質を持っている。このことは, 広葉雑草で遮光力の強い シロザやオオイヌタデと競合しやすい低温の時期におけ る播種では, その後の再生に影響する危険がある。た だ，シロザ，オオイヌタデはいずれも刈取り後の再生力
が弱い特性があるので, 早期の刈取り（掃除刈り）の効 果を期待でき，今後の検討課題であろう。

（2）ローズグラスの出芽最低温度はメヒシバよりも やや低いようであるが，オオイヌタデに比べると高い。 しかも，初期生育に必要な温度もメヒシバと同程度に高 い特性を持っている。したがって，シロザ，オオイヌタ デなどと競合しやすい低温時期における播種では，雑草 の抑制をうける危険性がきわめて強いと考えられる。し かし, これらの雑草は刈取り後の再生が弱く, 一方，口 ーズグラスは比較的遮光後における再生力が強いので, 両者の競合の場合には掃除刘りが有効と考えられる。な お，ローズグラスはその出芽に高い土壤水分を必要とす る特性がある。夏生 (早, 中) 雑草.の発生する $10 \sim 15^{\circ} \mathrm{C}$ の気温の時期は, わが国の暖地では比較的乾燥しやすい ので，畑地かんがいによる水補給が必要となろう。

以上の上うに，その出芽・生育のた如に比較的高温, 高 土壤水分条件を必要とするローズグラスにとって, 気温 も上昇し多雨になる梅雨期に入ってからが播種の適期と 考えられる。この場合, メヒシバなどの夏生 (晚) 雑草 との競合が生じる。しかもメヒシバなどは刚取り後の再 生力も強いので，それに対する対策が必要となろう。

\section{7. 摘要}

暖地型牧草の出芽・生育に及ぼす環境条件掞よび刈取 り後の再生力などについて, 雑草と対比して検討を行な い, 次の結果を得た。

1）暖地型牧草の競合草種は, 関東地方平坦部におい て, $4 \sim 5$ 月上旬 (日平均気温 $10 \sim 15^{\circ} \mathrm{C}$ ) 播種では, シ ロザ，オオイヌタデ，イヌビュなど，5月下旬以降 (20 ${ }^{\circ} \mathrm{C}$ 以上）の場合は，メヒシバ，スベリヒュ，カヤッリグ サなどであると推定された。

2）シコクビエは低温発芽性がすぐれ，その後の初期 生育も寸みやかであった。ローズグラスは低温発芽性が シコクビエやオオイヌタデには劣るが，メヒシバよりは すぐれた。初期生育は $15 \sim 25^{\circ} \mathrm{C}$ の温度条件でメヒシバ とほぼ同様であった。

3）ローズグラスの出芽・生青に及ぼす土壤水分の影 響は大きく, 出㭞・初期生育とも， $6 \mathrm{~mm}$ か九水/日 $>4$ $\mathrm{mm} /$ 日 $>2 \mathrm{~mm} /$ 日 であった。とくに $2 \mathrm{~mm} /$ 日 のかん 水で著しく劣った。

4）遮光後の刈取りによる再生力は，ローズグラスは 比較的強かったが，シコクビエは遮光により生育が抑制 され，著しく弱かった。

5）刈取り後の雑草の再生力は，メヒシバ，イヌビ ユ，スベリヒユが強く，次いでカヤッリグサで，オオイ 
ヌタデ，シロザはきわめて弱かった。

本試験を遂行するにあたり，助言と援助を賜った農事

試験場畑作部高林 実技官に深謝する。

引用文 献

1）荒井正雄 - 宮原益次 - 横森秀文 : 関東東|山農試報告 8， 47 55
(1955).

2) 荻木和典 : 農業技術 31 (2), 53 58 (1976).

3）菅野考已・中野淳一・江柄勝婎：四国费試報告 26, 53 70 (1973).

4）岡本恭二：農事試研報 24, 1 56 (1976).

5) 嶋村匡俊 : 雑草研究 10, 10 14 (1970).

6) 竹村昭平・長瀬嘉迪・紊藤栄成: 雑草研究 3, 96 101 (1964).

(1976 年 6 月 14 日受付)

\title{
Effect of Environmental Conditions on Emergence and Growth of Warm Season Grass
}

\author{
Katsuyoshi Noguchi and Kanenori NaKayama \\ Central Agricultural Experiment Station, Kitamoto, Saitama
}

\section{Summary}

The effects of environmental conditions on the emergence and growth of warm season grass, the regrowth vigour after cutting and others were studied as compared with weeds.

The results were as follows:

1. It was estimated that the competitive weeds of warm season grass were common lamb' s-quarters (Chenopodium album L.), Polygonum lapathifolium L. subsp. nodosum Kitam., and livid amaranth (Amaranthus lividus L.) in case of seeding from April to the first ten days of May (the average daily air temperature $10 \sim 15^{\circ} \mathrm{C}$ ), and large crabgrass (Digitaria adscendens Henr.), common purslane (Portulaca oleracea L.) and Chufa (Cyperus microiria Steud.) in case of seeding on the last ten days of May or later (over $20^{\circ} \mathrm{C}$ ) in the Kanto plain.

2. African millet (Eleucine coracana (L.) Gaerth.) surpassed other species in low temperature germeability and grew rapidly after emergence. Low temperature germeability of Rhodes grass (Chloris gayana Kunth) was inferior to African millet or P. lapathifolium L., but was superior to large crabrass. The early growth of Rhodes grass was about the same as large crabgrass at the conditions of the average daily air temperature $15 \sim 25^{\circ} \mathrm{C}$.

3. Soil moisture content affected greatly the emergence and growth of Rhodes grass. Namely, both emergence and growth in $6 \mathrm{~mm}$ watering per day were better than 4 or $2 \mathrm{~mm}$ watering, and $2 \mathrm{~mm}$ watering was extremely inferior to others.

4. The ability of regrowth by cutting after shading treatment of Rhodes grass was stronger than African millet. The growth of African millet was supressed in shading condition.

5. Large crabgrass, livid amaranth and common purslane had the ability of strong regrowth after cutting, and Chufa was medium. P. lapathifolium L. and common lamb' s-quarters were weak. 